\title{
Thinking about the Improvement of China's Income Statement
}

\author{
Zhihong LIN ${ }^{1}$ and Xiangyuan $\mathrm{CHU}^{2}$ \\ ${ }^{1}$ Department of Economics and Management North China Electric Power University, Hebei Province, China \\ ${ }^{2}$ Department of Economics and Management North China Electric Power University, Hebei Province, China \\ lzh13730225252@163.com,_chuxyco@sina.com
}

\begin{abstract}
The income statement is an important part of the financial statements, playing an important role in guiding people to make investment decisions, but the inherent limitations of the income statement has misled people a lot. This paper studies the current situation and puts forward improved methods in order to make the information disclosure of the income statement more reasonable.
\end{abstract}

Index Terms - income statement, limitations, improved methods

\section{Introduction}

Income statement is one of the three financial statements. It reflects the enterprise production and operation results in a certain accounting period, for example monthly, quarterly, semi-annually or annually. It reveals the various revenues and all the costs of the enterprise at a specific period, and the enterprise's profits or losses incurred. The main purpose of the preparation of the income statement is to show the outcome of business information, providing a variety of reports to users as a basis for their decisions or reference. The main effect of the income statement is to explain business operating results and profitability, to evaluate the solvency of the enterprise, to help the managers to make business decisions and to examine the performance of the managers.

However, the limitations inherent in the current income statement lead to its role greatly reduced, while misleading the report information users, reducing the usefulness of the information, thus weakening the credibility of the income statement. Based on this point, this paper studies the current situation and puts forward improved methods in order to make the information disclosure of the income statement more reasonable.

\section{Limitations Exist in the Current Income Statement}

\section{A. Simple Structure}

Balance sheet and income statement both reflect three accounting elements, but the balance sheet has more lines than the income statement. The balance sheet has detailed classification of each accounting element, while the income statement only classify revenue elements as operating income, thus reflecting less information.

\section{B. Not Fully Reflect the Principle of Prudence}

Impairment of assets generally use impairment losses on assets to reflect, which fully embodies the principle of prudence. Income in the income statement is overrated. Because there is no distinction among different types of income, for example cash and credit business income are both reflected in operating income, without considering the credit risk. At the same time there is no distinction between shortterm credit business income and long-term credit business income, and without considering the risk of long-term credit sales revenue. But selling on credit may involve in commercial secrets. Enterprises can disclose some in accordance with the actual situation, not necessarily all.

\section{Some Indicators can not be Provided}

Such as gross profit and EBIT (earnings before interest and tax).Gross profit reflects the enterprise's profit space. Enterprise's net profit is a result of deductions of period charge and income tax. If the period charge is more than expected, it will erode the profitability of the product itself, which can not truly reflect the product's market adaptability, price advantage and other information, resulting in false impression. The more the gross profit, the greater the profitability of the enterprise and the stronger the competition of the enterprise, which is hard for net profit to express.

\section{Some Redundant Index}

For example sales tax and extra charges. Before the change from BT (business tax) to VAT(value-added tax), sales tax was included in sales tax and extra charges. After the change from BT to VAT, business tax composes of city maintenance and construction tax, education supplementary tax, while vehicle and vessel tax, stamp tax are excluded, which is unreasonable.

\section{E. Unreasonable Caliber}

For example, financial expenses belong to financing activities in cash flows statement, but belong to operating activities in income statement. Investment income, profit or loss on fair value belong to investment activities in cash flows statement, but belong to operating activities in income statement.

F. $\quad$ Non-operating Revenue and Expenditure has Overlap with Gains and Losses

According to the definition of profits, business results mainly consist of two parts: One is economic inflow and outflow of daily activities. This part of the economic content is mainly expressed by "income" and "expenses". The other comes from non-routine activities, and was included in gains and losses of current period. But this part does not has an independent accounting element. 
G. A Part of the Added Value of the Asset is not Reflected in the Return Information

The current accounting standard for business enterprises has adopted different ways to deal with the changes in the fair value of the assets that is measured in the fair value. One part of it is included in the current gains and losses, such as the changes in the fair value of trading financial assets; the other part of it is included in $\mathrm{OCI}$ (other comprehensive income), such as the changes in the fair value of available-forsale financial assets. But the changes in the fair value of the fixed assets and the inventory that is measured in historical cost are only confirmed when the assets are sold. This is easy to cause the enterprise to use the fair value to carry on the earnings management.

H. the Position of the Changes in the Fair Value is Controversial

It is controversial that whether the profit of the fair value's changes should be included in operating profit. It is seen as a part of the operating profit in our country's income statement, while it is listed behind the operating profit in the international accounting standards, the American accounting standards and EU accounting standard. The author suggests to set up gains and losses account and thus the gains on the changes in the fair value should be included in the account.

\section{The Improvement of the Current Income Statement}

\section{A. Distinguish Different Income Statement and its Composition}

Incomes and profits are from operating activities, investing activities, financing activities and other special activities. The users of the statement can accurately judge the income risk according to the proportion of all income in total income, especially can clear the income by operating activities in order to determine enterprise's profit quality.

\section{B. Fully Reflect the Principle of Prudence}

In accounting, the definition of income ignores the limit of time, and this has great influence on the income statement. So it is necessary to do special treatment on the long-term credit income. One is not recognized as income for the time being, the other is to conduct offsetting.

\section{Reflect the Important Indicators}

Goss profit and EBIT in the reflection of the enterprise's profit space, product market competition and other aspects are more clearly than the operating profit. So the two indicators should be added to the profit table.

\section{Remove Redundant Index}

Such as sales tax and extra charges. The rest taxes after the change from BT to VAT should be included in the period charge.

\section{E. Consistent with Cash Flows Statement}

The balance sheet and the income statement should have the same caliber, and then the same enterprise in different periods and the operating conditions of different enterprises in the same period is more comparable.

\section{F. Set Up Gains and Losses Account}

Set up gains and losses account individually which included in current profits and losses. This approach is consistent with the definition of profit and also make the unity of the items in the income statement.

\section{G. Add the Project to Confirm Appreciation in Asset Value}

Assets value-added process should be regulated. The benefit from the changes in fair value of fixed assets and inventories, etc. should be confirmed. Or refer to the United Kingdom accounting standards, prepare a list of gains and losses, and disclose relevant information in the notes to the financial statements.

\section{Conclusion}

The improved profit table solves some unreasonable places in the actual work, so that the income statement can better meet the national conditions of our country, and also disclose accounting information more reasonable.

\section{Acknowledgment}

X.Y.C thanks Z.H.L for guidance, which is of great help.

\section{References}

[1] Y. He, X. Li, and S. Gan, "Review and evaluation of the income statement's improvement plan," Finance and Accounting Monthly, pp. 55-57, August 2012.

[2] R. Zhang, "The improvement and perfection of the income statement," Industry and technology forum, vol. 11, no. 13, pp. 230-231, March 2012.

[3] Y. Wu, "Thinking of the income statement on the basis of financial analysis," Friends of Accounting, no. 11, pp. 29-31, 2015. 